\title{
History of the Pollution in Tomsk Region (Siberia, Russia) According to the Study of High-Moor Peat Formations
}

\author{
Antonina Mezhibor ${ }^{1 *}$, Sergey Arbuzov ${ }^{1}$, Leonid Rikhvanov ${ }^{1}$, Francois Gauthier-Lafaye ${ }^{2}$ \\ ${ }^{1}$ Department of Geoecology and Geochemistry, Tomsk Polytechnic University, Tomsk, Russia \\ ${ }^{2}$ Centre de Géochimie de la Surface, EOST, CNRS/ULP, Strasbourg, France \\ E-mail:amezhibor@gmail.com \\ Received January 27, 2011; revised June 28, 2011; accepted August 26, 2011
}

\begin{abstract}
A method that could be used to detect the change of the environment was used to determine the input of trace elements from the atmospheric fallouts into the biosphere near Tomsk city (West Siberia, Russia) during the last century. In this study we used high-moor peat formations because of the wide-spread occurrence of bogs in this region. Investigations of the raised peat bogs in areas with different degree of anthropogenic impact showed that the distribution of trace elements in the upper parts of peat deposits depends on the location of bogs towards industrial sources. The highest concentrations of $\mathrm{Ca}, \mathrm{Fe}, \mathrm{Cr}, \mathrm{Co}, \mathrm{Sc}, \mathrm{Hf}$ and rare earth elements were found in the upper part of the bog located near the city Tomsk. Distribution of trace elements in the vertical profiles of raised peat deposits near cities Tomsk and Seversk reflects the industrial specialization of these cities and the dynamic of the atmosphere pollution. Studies of radioactive elements $\left({ }^{137} \mathrm{Cs},{ }^{238} \mathrm{Pu},{ }^{239} \mathrm{Pu}\right)$ have indicated their inputs from global fallouts.
\end{abstract}

Keywords: Atmosphere Pollution, High-Moor Peat, Trace Elements in Peat

\section{Introduction}

The development of industry and growing requirements of the mankind result in the environment pollution. Therefore studies on the determination of the degree of anthropogenic impact on the environment have been especially relevant during the last several years. The most commonly used compartments of the environment for the studies of anthropogenic contaminations are soil, natural water and snow. Investigations of these components allow us to receive a sufficiently complete characteristic of an environment state. However analysis and estimation of the environment change for a long time period require a considerable data amount.

The study of stratified formations (tree rings, sediments, glaciers, peat deposits, etc.) is relatively new and perspective direction of the studies of the ecological condition of environment and its change with time. Stratified formations are convenient material for the monitoring research of the aerogenic emissions of pollutants into the environment as this method does not need many samples and systematic observations under the environmental state. Moreover it allows us to follow a transformation dynamic of the environment for a longer period of time which considerably exceeds a period of systematic observations.

The method of the study of the biosphere state using peat deposits has the following advantages:

- wide spreading of bogs in the temperate climate zone of the northern hemisphere where contaminants are mainly concentrated;

- a property of the peat to keep different chemical elements, that hinders from their migration;

- $\quad$ an opportunity to obtain representative data using only some peat sections.

Stratified formations like peat deposits were chosen for the studies as they are widespread in Tomsk region, where $50 \%$ of the territory is marshlands. Raised or ombrotrophic peat deposits account for approximately $60 \%$ of all peat deposits of Tomsk region. Ombrotrophic peat deposits are mainly fed by atmospheric fallouts, thus they are perspective and widespread aerosol reservoirs [1-14]. Aerosols accumulated on the peatland surface are well kept by the peat and peat water.

The input of trace elements in peat deposits is determined first of all by the mineral composition of the underlying grounds and by surrounding dry lands. The wind soil erosion is also an important provider of the 
atmospheric dust (clay minerals). After their transporting and possible transformation, pollutants are eventually deposited on the bog surface by wet deposition, by dry or cloud (fog) water deposition. Because of the property of weak decomposition the Sphagnum bog can save particles, fallen from the atmosphere, without change.

The suitability of the raised peat bogs as environmental archives of modern and past atmospheric deposition is determined by the property of peat to hold for chemical elements. Usually the elements are not subjected to significant post-depositional dislocations because of special properties of the peat moss Sphagnum which forms peat deposits.

Anthropogenic sources of trace elements emissions into the atmosphere of Tomsk region are such industries as the thermal power industry $\mathrm{Fe}, \mathrm{Sc}, \mathrm{Hf}, \mathrm{Th}, \mathrm{Co}, \mathrm{Cr}$, $\mathrm{Sm}, \mathrm{Ce}, \mathrm{Rb}, \mathrm{Ta}, \mathrm{Cs})$, industry of nuclear-fuel cycle $\left({ }^{137} \mathrm{Cs}\right.$, $\mathrm{Sr}-90, \mathrm{U}, \mathrm{Pu}, \mathrm{La}, \mathrm{Ce}, \mathrm{Sm}, \mathrm{Eu}, \mathrm{Yb}, \mathrm{Lu}$ ), petrochemical and oil industry ( $\mathrm{Na}, \mathrm{Br}, \mathrm{Sb})$, and also the traffic [15]. Global fallouts is a source of a considerable part of radioactive elements input in peat deposits. The cities Tomsk and Seversk are objects that determine the ecological situation in the south part of Tomsk region.

\section{Material and Methods}

A lager part of Tomsk region is a part of the zone of om- brotrophic sphagnum bogs with the atmospheric nutrition ( $60 \%$ of all swamps). For the detail sampling and specialized study three raised peat deposits were chosen (Figure 1):

- Petropavlovsky Ryam, located in $27 \mathrm{~km}$ to the north from Tomsk city in the direction of predominated winds;

- Vodorazdelnoe, located in $35 \mathrm{~km}$ to the north-west from Tomsk city out of the zone of the direct influence of Tomsk and Seversk industries;

- Malaya Icha, located in $400 \mathrm{~km}$ to the west from Tomsk out of the influence of any industries.

- $\quad$ For the comparison and for the detection of global fallouts the published data on two bogs were also used: Kirsanovskoe [16], located in the southwestern direction from Tomsk, and Bakcharskoe [17], located in the north-western direction out of the industrial influence (Figure 1).

The bog Petropavlovsky Ryam is a typical pine-sphagnum bog. The main vegetation is represented by the Sphagnum, Ledum, Andromeda and Pinus palusiris. The bogs Vodorazdelnoe and Malaya Icha are also typical for Tomsk region. The botanical composition of the studied sections is presented at the Figure 2. The studied bogs are defined by the typical botanical composition in the upper part, including the bog Malaya Icha [18].

The upper parts of the peat bogs were sampled to the

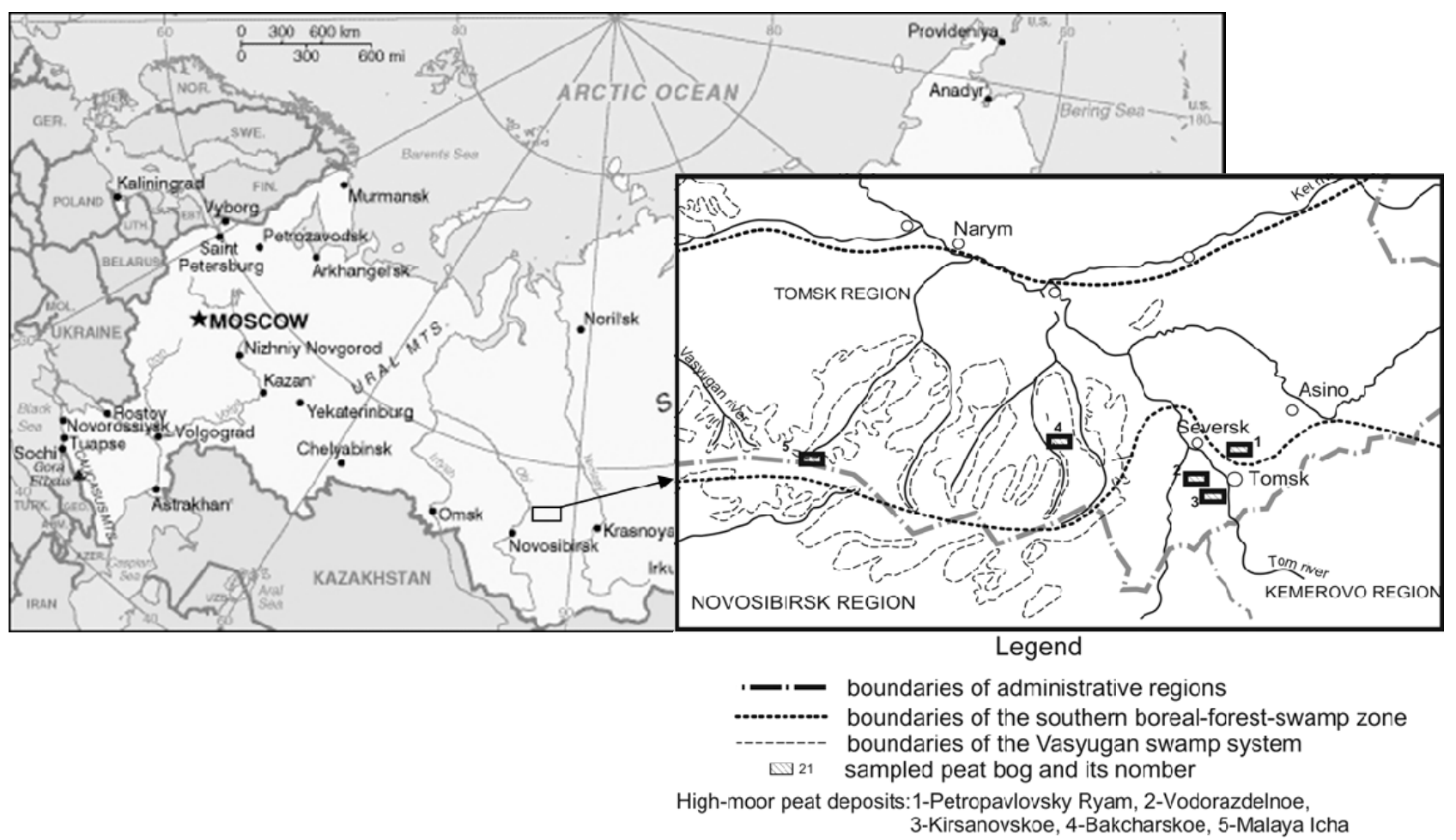

Figure 1. Location of studied peat deposits in Tomsk region. 


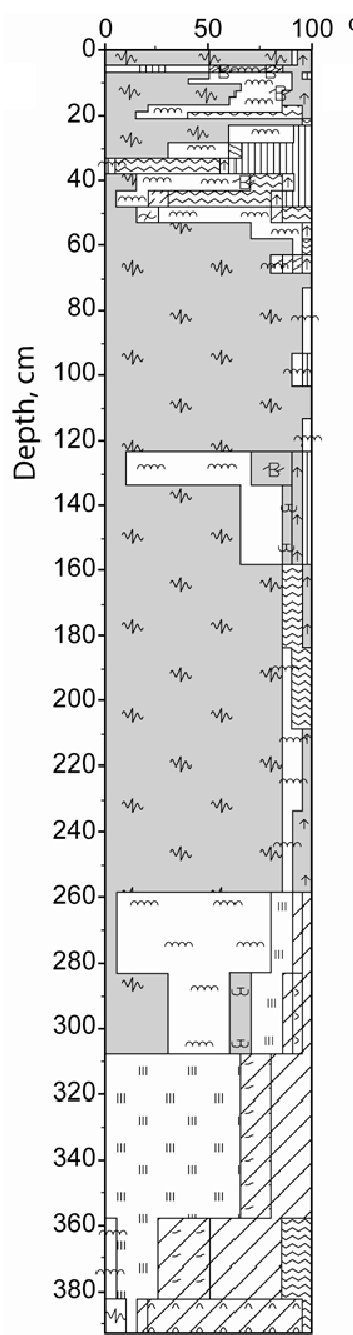

(a)

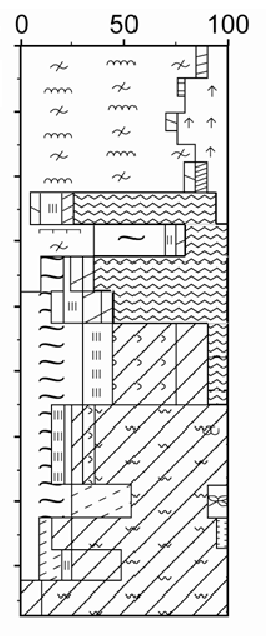

\begin{tabular}{|c|c|}
\hline$m$ & Sphagnum fuscum \\
\hline$m$ & S. magellanicum \\
\hline B & S. balticum \\
\hline$\uparrow \uparrow$ & Shrubs (Betula nana, Ledum, Chamaedaphne) \\
\hline & Eriophorum vaginatum \\
\hline$x x$ & S. angustifolium \\
\hline & Wood \\
\hline & Carex lasiocarpa, S. rostrata \\
\hline$\infty w$ & S. teres \\
\hline & Carex limosa \\
\hline & Carex elata ssp. omskiana \\
\hline III III & Schuchzeria palustris \\
\hline 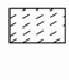 & $\begin{array}{l}\text { Brown moss (Drepanocladus, Homatocaulis, } \\
\text { Warnstorfia, Calliergon, Meesia) }\end{array}$ \\
\hline$\sim$ & S. centrale, S. warnstorfii \\
\hline $6 / 8$ & Carex juncella, C. cespitosa \\
\hline$\$$ & Menyanthes trifoliata \\
\hline & Phragmites australis \\
\hline
\end{tabular}

(b)

Figure 2. Botanical composition of the sections of the bogs: (a) Petropavlovskiy Ryam, (b) Vodorazdelnoe.

depth of $30 \mathrm{~cm}$ by the method of the trial pit. Below this interval samples were collected using geological peat drill (with a volume of $50 \mathrm{~cm}^{3}$ ) to the bottom of the peat deposits. Intervals of sampling were ranged from 2 to 10 $\mathrm{cm}$ (at the upper part of the peat bogs) to $25 \mathrm{~cm}$ (below $100 \mathrm{~cm})$.

The samples were dried at room temperature and than were reduced to powder. After that the moisture, degree of decomposition and botanical composition were determined in all samples.

For analytical investigations of peat the method of instrumental neutron-activation analysis (INAA) is more perspective as it does not need for special sample preparation and has a low detection limit [19]. Analysis of the peat samples was realized at the Nuclear-Geochemical Laboratory of the Department of Geoecology and Geochemistry of Tomsk Polytechnic University (TPU) (ana- lysts A.F. Sudyko and L.V. Bogutslaya). The laboratory works on the basis of the nuclear reactor IRT-T of the Research Institute of Nuclear Physics of TPU. The absence of chemical preparation excludes errors from the influx and removal of chemical elements with reagents. The density of thermal neutron flux was $2 \cdot 10^{13}$ neutron. $\left(\mathrm{cm}^{2} \cdot \mathrm{sec}\right)^{-1}$, duration of the exposure was 20 hours. The measurement was carried out at the multi-channel analyzer of impulse AMA 02F with the semiconducting GeLi detector.

The quality of the INAA is confirmed by the results of the analysis of standard samples of comparison (Table 1).

The specific activity measurements for ${ }^{137} \mathrm{Cs}$ and ${ }^{210} \mathrm{~Pb}$ were carried out by the gamma-spectrometric analysis [20]. The specific activity measurements for $\mathrm{Pu}$ were carried out by the alpha-spectrometric analysis [20]. For 
Table 1. Contents of trace elements in the international standards USGS CLB-1.

\begin{tabular}{|c|c|c|c|c|c|c|}
\hline & \multicolumn{6}{|c|}{ USGS CLB-1 } \\
\hline & Methods & & & & & INAA(Tomsk) \\
\hline & & value & error & value & error & \\
\hline Minor elements & & $\%$ & & $\%$ & & \\
\hline $\mathrm{Fe}$ & AAS, INAA & 0.874 & 0.050 & & & 0.87 \\
\hline $\mathrm{Na}$ & INAA, FES & 0.017 & 0.002 & & & 0.25 \\
\hline $\mathrm{Ca}$ & IDMS, INAA, FES, XRF & 0.157 & 0.01 & & & 0.19 \\
\hline Trace elements & & $\mathrm{mg} / \mathrm{g}$ & & $\mathrm{mg} / \mathrm{g}$ & & \\
\hline As & HGAAS & & & 13 & & 11.0 \\
\hline $\mathrm{Cr}$ & INAA, ICP-AES & 9.7 & 1.2 & & & 9.74 \\
\hline Th & IDMS, INAA & & & 1,40 & & 1.62 \\
\hline $\mathrm{U}$ & IDMS, INAA & & & 0,55 & & 0.55 \\
\hline V & INAA & 12.0 & 1.0 & & & \\
\hline $\mathrm{Zn}$ & AAS, IDMS, INAA & 48.0 & 4.0 & & & 49.2 \\
\hline $\mathrm{Sb}$ & INAA & & & 1,50 & & 1.38 \\
\hline $\mathrm{Ce}$ & INAA & 10.0 & 1.6 & & & 10.2 \\
\hline Co & INAA, FES & 7.0 & 0.7 & & & 6.64 \\
\hline $\mathrm{Sc}$ & INAA & 2.0 & 0.1 & & & 1.88 \\
\hline $\mathrm{Rb}$ & IDMS, INAA, FES & 5.2 & 0.9 & & & 5.5 \\
\hline $\mathrm{Ba}$ & INAA & 34.0 & 5.0 & & & 40.0 \\
\hline $\mathrm{La}$ & INAA & & & 5,00 & & 4.8 \\
\hline
\end{tabular}

these measurements only the upper parts of the peat cores were used (100 $\mathrm{cm}$ from the surface), taking into consideration the anthropogenic nature of radiocesium and plutonium and short half-live period of ${ }^{210} \mathrm{~Pb}$.

\section{Results and Discussion.}

The bog Petropavlovsky Ryam was chosen as the main object for the research as it is located near the industrial zone-Tomsk-Seversk industrial agglomeration. Contents of most trace elements in the peat samples of the upper part of this bog are significantly higher than in other bogs (Table 2). The ash yield is also high and riches $14 \%$ in the interval ranged from 17 to $19 \mathrm{~cm}$. Concentrations of trace elements in the other studied bogs are approximately equal. There are some differences in concentrations of $\mathrm{Cr}, \mathrm{Fe}, \mathrm{Br}, \mathrm{Sr}, \mathrm{La}$ and $\mathrm{Au}$ (Table 2).

The highest concentrations of all studied elements in the bog Petropavlovsky Ryam are characteristic for the interval ranged from 17 to $19 \mathrm{~cm}$, which corresponds to the period of the intensive nuclear tests in the atmosphere in 1961-1963 (according to the ${ }^{210} \mathrm{~Pb}$ measurements in this interval [20]) (Figure 3(a)). High concentrations of trace elements in the upper part of this bog, which corresponds to the $2^{\text {nd }}$ part of the $20^{\text {th }}$ century, are explained by the influence of industries of the cities Tomsk and Seversk. High contents of many trace elements in the peat bogs can be a result of coal combustion: As, $\mathrm{Ba}, \mathrm{Co}$,
$\mathrm{Cr}, \mathrm{Sb}, \mathrm{Ce}, \mathrm{La}, \mathrm{U}, \mathrm{Rb}, \mathrm{Th}, \mathrm{Ag}[21,22]$. For example, emissions of $\mathrm{Cr}$ from coal combustion are $\approx 44 \%$ from all anthropogenic sources in the atmosphere [22]. $\mathrm{Ba}, \mathrm{Sr}$, $\mathrm{Rb}, \mathrm{U}, \mathrm{Th}, \mathrm{Au}$ and lanthanides are the elements characteristic for coals of Kuznetsky coal basin [23], which have been used at thermal power stations of the cities. High concentrations of $\mathrm{Sb}, \mathrm{Na}$ and $\mathrm{Br}$ are probably connected with the petroleum-chemical plant, situated to the north of Tomsk [24].

Vodorazdelnoe bog is situated out of the zone of the intensive impact of the Tomsk-Seversk industrial agglomeration. The bog is also located close to it and is also subjected to the pollution but to a lesser degree than the bog Petropavlovsky Ryam. These two bogs well reflect the beginning of the industrial development at the second part of the $20^{\text {th }}$ century, according to the accumulation of $\mathrm{Ca}, \mathrm{Fe}, \mathrm{Cr}, \mathrm{Co}, \mathrm{Sc}, \mathrm{Hf}$ and rare earth elements (Figures 3(a) and (b)). The accumulation of many trace elements in the upper part of the peat bogs (the upper 25 $\mathrm{cm}$ for the bog Petropavlovsky Ryam and $50 \mathrm{~cm}$ for the bog Vodorazdelnoe) indicates this.

In the sections of the peat deposits Kirsanovskoe and Bakcharskoe which are located out of the industrial influence zone there have not been found high contents of trace elements in the upper parts of peat bogs excepting the interval corresponding to the period of the intensive nuclear tests in 1961-1963 (Figures 3(c) and (d)).

The comparison of average contents of trace elements 
Table 2. Mean concentrations of trace elements in the upper $50-\mathrm{cm}$ layer of the peat deposits.

\begin{tabular}{|c|c|c|c|c|c|}
\hline \multirow{2}{*}{ Elements } & \multicolumn{5}{|c|}{ Mean contents of trace elements, ppm } \\
\hline & Malaya Icha & Bakcharskoe & Kirsanovskoe & Vodorazdelnoe & Petropavlovskiy Ryam \\
\hline $\mathrm{Na}(\%)$ & 0.03 & 0.04 & - & - & 0.09 \\
\hline $\mathrm{Ca}(\%)$ & 0.24 & 0.57 & - & - & 0.43 \\
\hline $\mathrm{Sc}$ & 0.33 & 0.40 & 0.61 & 0.49 & 1.61 \\
\hline $\mathrm{Cr}$ & 3.3 & 2.8 & 4.0 & 9.1 & 14.7 \\
\hline $\mathrm{Fe}(\%)$ & 0.12 & 0.27 & 0.18 & 0.17 & 0.46 \\
\hline Co & 0.34 & 1.11 & 0.87 & 0.81 & 2.77 \\
\hline $\mathrm{Br}$ & 6.8 & 16.8 & 1.5 & 7.1 & 4.6 \\
\hline $\mathrm{Rb}$ & 6.9 & 6.0 & 3.8 & - & 11.4 \\
\hline $\mathrm{Sr}$ & 25.0 & 52.3 & 16.2 & - & 59.3 \\
\hline $\mathrm{Sb}$ & 0.17 & 0.22 & 0.89 & 0.35 & 0.39 \\
\hline Cs & 0.14 & 0.31 & 0.22 & 0.19 & 0.92 \\
\hline $\mathrm{Ba}$ & 35.0 & 49.5 & 26.4 & - & 117.0 \\
\hline $\mathrm{La}$ & 0.88 & 1.00 & 1.42 & 2.22 & 3.74 \\
\hline $\mathrm{Ce}$ & 1.7 & 2.7 & - & 2.2 & 9.1 \\
\hline $\mathrm{Sm}$ & 0.17 & 0.29 & - & 0.33 & 0.69 \\
\hline $\mathrm{Eu}$ & 0.04 & 0.04 & - & 0.08 & 0.17 \\
\hline $\mathrm{Tb}$ & 0.02 & 0.03 & - & 0.04 & 0.11 \\
\hline $\mathrm{Yb}$ & 0.09 & 0.08 & 0.13 & 0.13 & 0.37 \\
\hline $\mathrm{Lu}$ & 0.02 & 0.01 & - & 0.01 & 0.05 \\
\hline $\mathrm{Hf}$ & 0.09 & 0.11 & 0.24 & 0.30 & 0.76 \\
\hline $\mathrm{Ta}$ & 0.03 & - & - & - & 0.21 \\
\hline $\mathrm{Au}$ & 0.004 & 0.31 & - & 0.01 & 0.004 \\
\hline Th & 0.25 & 0.27 & 0.38 & 0.33 & 1.7 \\
\hline $\mathrm{U}$ & 0.12 & 0.08 & 0.22 & 0.24 & 0.66 \\
\hline $\operatorname{Ad}(\%)$ & 2.2 & 3.0 & 3.9 & 4.0 & 5.9 \\
\hline
\end{tabular}

Ad—ash yield; "_"— an element has not been determined.

in the upper 50-cm layers of the peat sections showed a regular changing of element concentrations depending on the location of the studied bogs (Figure 4). Thus, the highest concentrations of trace elements accumulated in the upper part of the Petropavlovskiy Ryam bog, which is closest to the cities Tomsk and Seversk. The bog Malaya Icha was used as a background as it is located far from industrial regions. This bog is characterized by the lowest element concentrations (Figures 3(e) and 4).

Comparing the bogs of the territories with different degree of industrial load a regular variation of trace elements in the upper parts of peat deposits depending on the location of the bogs has been noticed. The bog Petropavlovsky Ryam is subjected to the maximum degree of contamination (Figure 4).
Taking into account the close location of the Siberian Chemical Combine (SCC, the enterprise of nuclear fuel cycle) in Seversk to the bog Petropavlovsky Ryam the concentrations of cesium and plutonium were determined [20]. These elements are "indicative" trace elements for the industry of SCC.

High concentrations of radioactive cesium were fixed in some intervals: from 5 to $7 \mathrm{~cm}$, from 11 to $13 \mathrm{~cm}$, from 15 to $17 \mathrm{~cm}$, and from 17 to $19 \mathrm{~cm}$ (Figure 5). The last one corresponds to 1961-1963. The others are probably connected with the work of SCC. At the peat bog Kirsanovskoe the high cesium concentration is only found in one interval ranging from 7 to $12 \mathrm{~cm}$ (Figure 6), which corresponds to the early 60s [16].

Plutonium distribution in the peat deposit Petropav- 


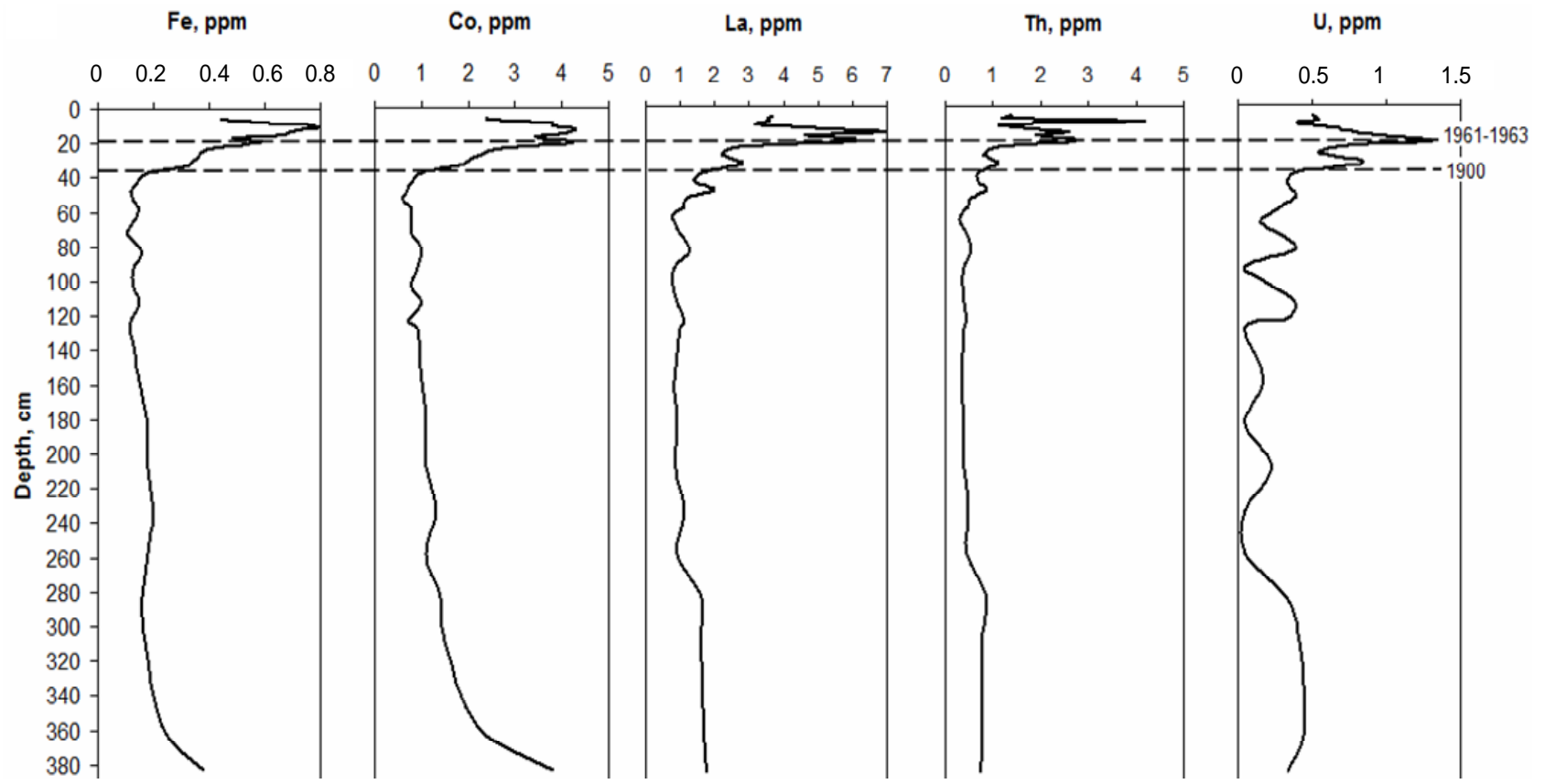

(a)

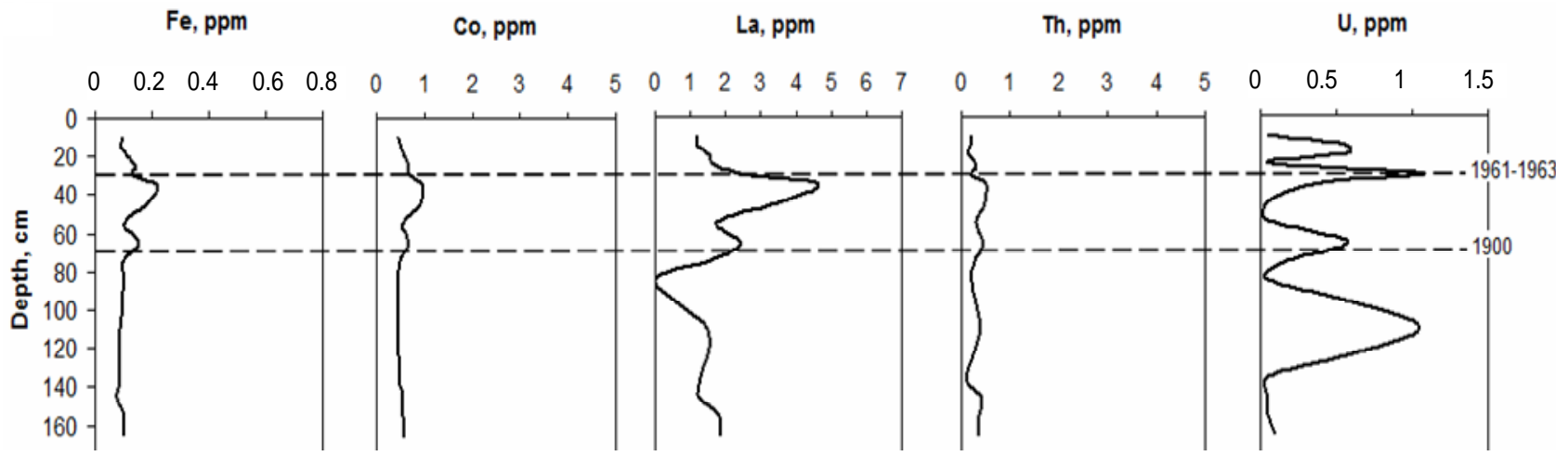

(b)

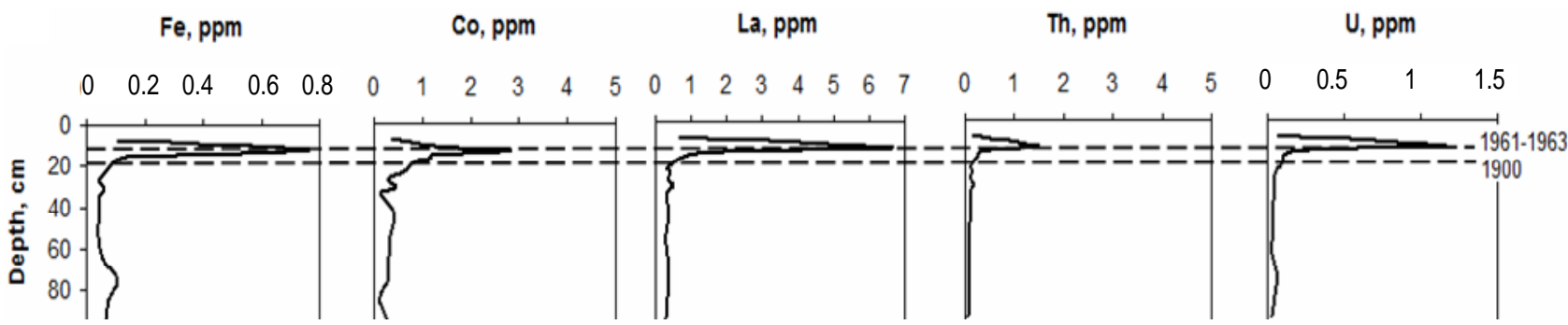

(c)
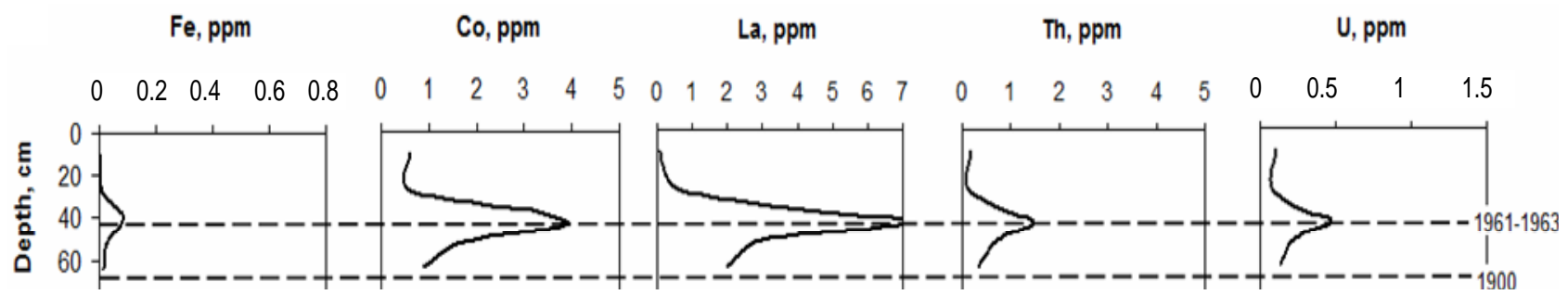

(d) 


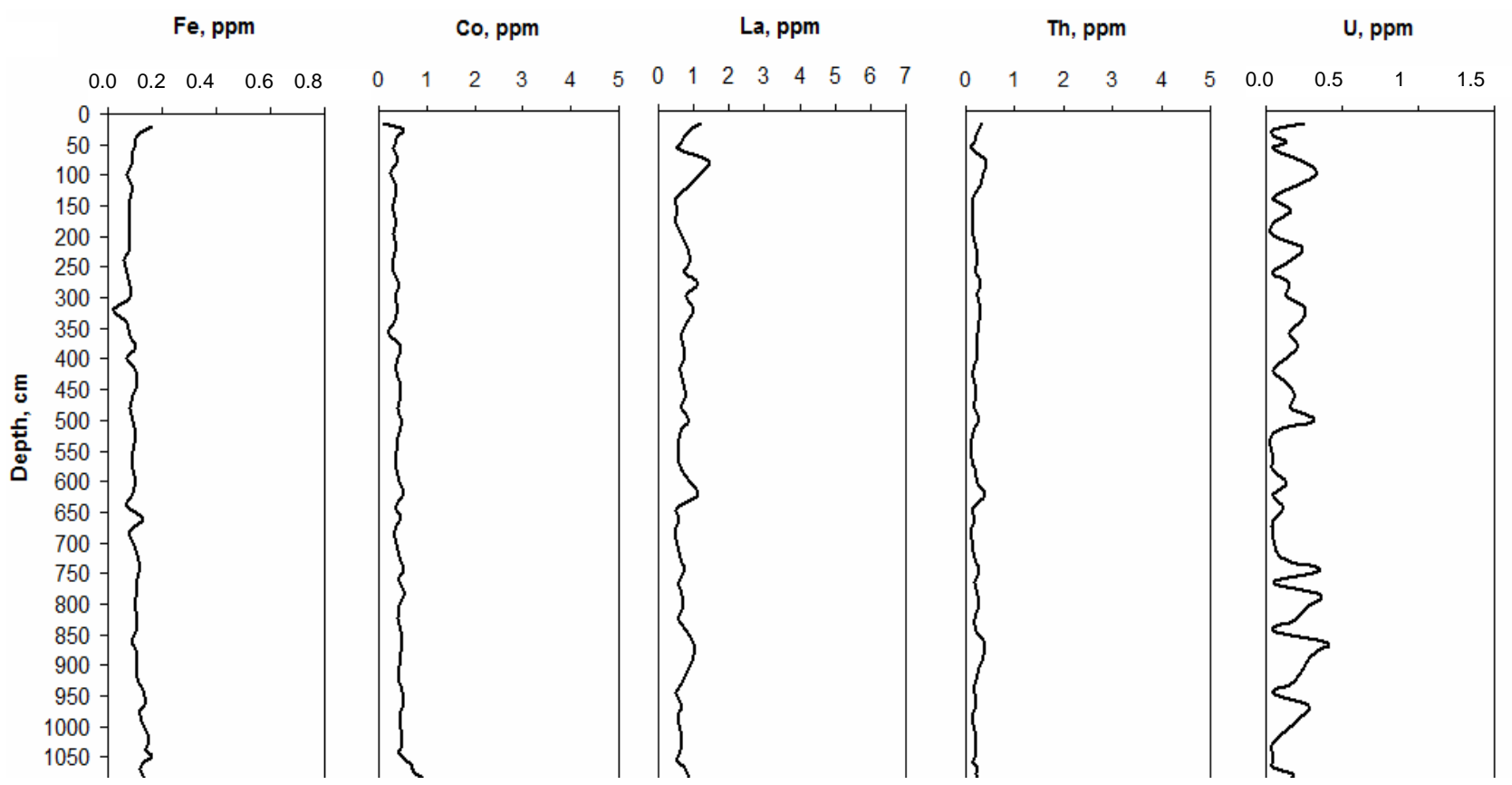

(e)

Figure 3. Distribution of some trace elements in peat bogs: (a) Petropavlovsky Ryam; (b) Vodorazdelnoe; (c) Kirsanovskoe (according to the data of V.M. Gavshin et al., 2003); (d) Bakcharskoe (according to the data of V.A. Bobrov et al., 2006; (e) Malaya Icha.

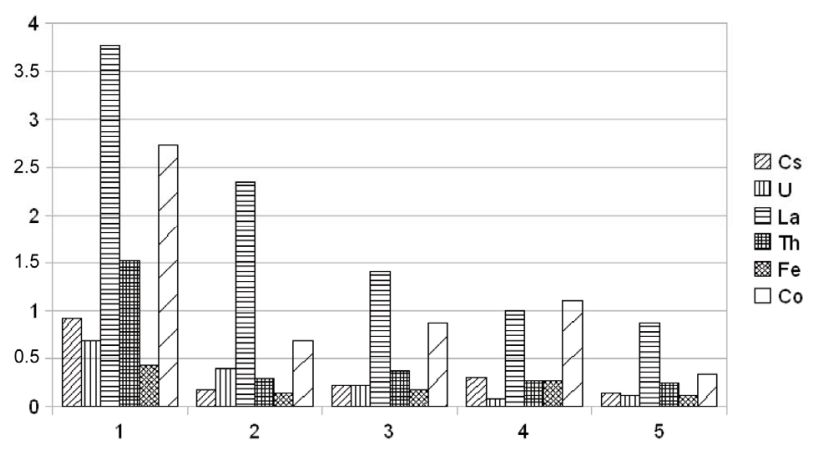

Figure 4. Average concentrations of some trace elements in the upper $50-\mathrm{cm}$ layer of the peat deposits: 1-Petropavlovsky Ryam, 2-Vodorazdelnoe, 3-Kirsanovskoe, 4-Bakcharskoe, 5-Malaya Icha.

lovsky Ryam has three peaks in the intervals (Figure 7):

- $\quad$ from 19 to $21 \mathrm{~cm}$ (1961-1963, period of the intensive nuclear tests);

- $\quad$ from 13 to $15 \mathrm{~cm}$ (corresponding to the late $70 \mathrm{~s}$ ).

- $\quad$ from 7 to $9 \mathrm{~cm}$ (the beginning of the 90s).

The first interval with the highest plutonium concentrations has both the local and global sources of plutonium fallouts and other two intervals have probably the local source [20]. The interval ranged from 7 to $9 \mathrm{~cm}$ in the distribution of radioactive elements reflects the incident at SCC in 1993.

The fallouts of the Siberian Chemical Combine in-

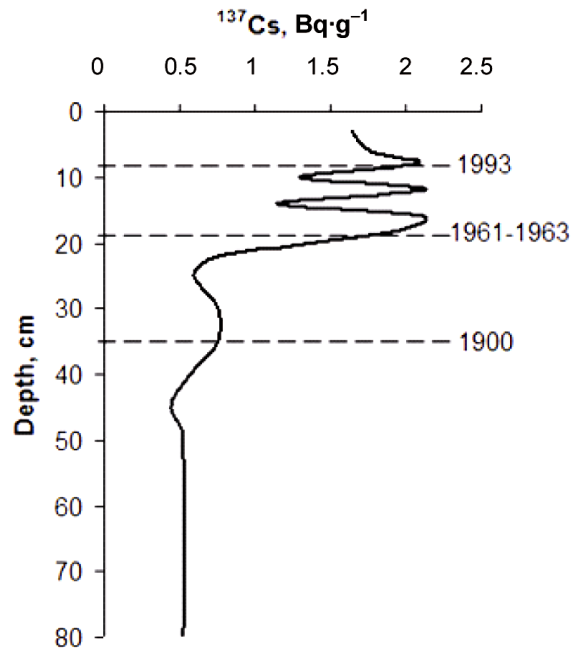

Figure 5. Distribution of cesium in the section of the bog Petropavlovsky Ryam.

clude a wide range of contaminating trace elements. Besides radioactive elements there are high concentrations of lanthanides in the fallouts of SCC [25].

\section{Conclusions}

Peat formations are unique ecosystems which can save the history of environmental pollution, which make them suitable for environmental monitoring. Studies of raised 


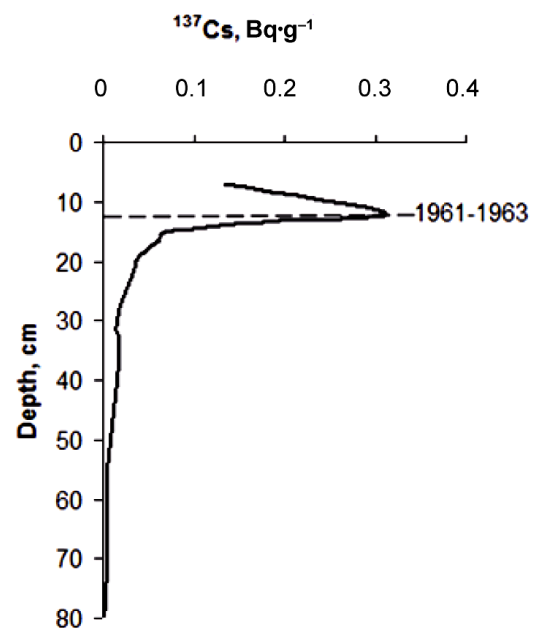

Figure 6. Distribution of cesium in the section of the bog Kirsanovskoe (according to the data of V.M. Gavshin et al., 2003).

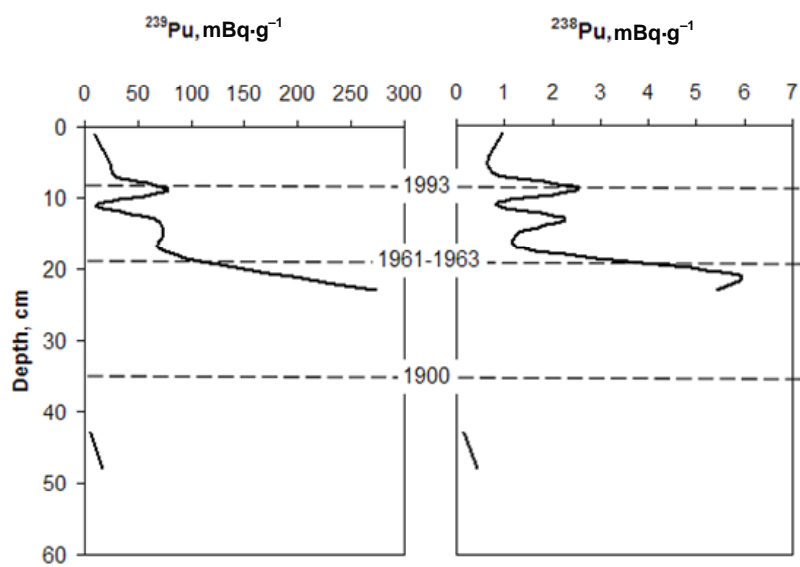

Figure 7. Distribution of plutonium isotopes in the section of the bog Petropavlovsky Ryam.

peat formations in Tomsk region showed the industrial pollution near the city Tomsk. High concentrations of trace elements in the upper part of peat formations indicate this.

The input of many of trace elements in peat bogs is realized from coal combustion: $\mathrm{Ba}, \mathrm{Sr}, \mathrm{Rb}, \mathrm{U}, \mathrm{Th}, \mathrm{Au}$, lanthanides and others. Radioactive elements and lanthanides are characteristic for the releases of enterprises of nuclear-fuel cycle such like SCC.

Concentrations of most elements in the peat of Petropavlovskiy Ryam bog have begun to increase after the $2^{\text {nd }}$ World War. That was connected with the intensive development of the industry during that period. All elements have the peaks in the interval ranging from 17 $\mathrm{cm}$ to $19 \mathrm{~cm}$, which corresponds to the period of 1961 1963. The peaks of the same period are characteristic for the bogs Vodorazdelnoe, Kirsanovskoe and Bakchar- skoe.

The studies on plutonium and cesium concentrations revealed global pollution from nuclear weapon tests in 1961-1963.

\section{Acknowledgements}

The research was supported by the grant of the Ministry of Education and Science of the Russian Federation (Number P1324, 11.06.2010)

\section{References}

[1] F. De Vleeschouwer, L. Gérard, C. Goormaghtigh, N. Mattielli, G. Le Roux and N. Fagel, "Atmospheric Lead and Heavy Metal Pollution Records from a Belgian Peat Bog Spanning the Last Two Millennia: Human Impact on a Regional to Global Scale," Science of the Total Environment, Vol. 377, 2007, pp. 282-295. doi:10.1016/j.scitotenv.2007.02.017

[2] W. A. Glooschenko and J. A. Capobianco, "Metal Content of Sphagnum Mosses from Two Northern Canadian Bog Ecosystems," Water, Air and Soil Pollution, Vol. 10, 1978, pp. 215-220. doi:10.1007/BF00464716

[3] M. Görres and B. Frenzel, "Ash and Metal Concentrations in Peat Bogs as Indicators of Anthropogenic Activity," Water, Air and Soil Pollution, Vol. 100, No. 3, 1997, pp. 355-365. doi:10.1023/A:1018324525914

[4] A. D. Headley, 'Heavy Metal Concentrations in Peat Profiles from the High Arctic," The Science of the Total Environment, Vol. 177, No. 1-3, 1996, pp. 105-111. doi:10.1016/0048-9697(95)04867-7

[5] H. Kempter and B. Frenzel, "The Impact of Early Mining and Smelting on the Local Tropospheric Aerosol Detected in Ombrotrophic Peat Bogs in the Harz, Gemany," Water, Air, and Soil Pollution, Vol. 121, 2000, pp. 93108. doi:10.1023/A:1005253716497

[6] A. B. MacKenzie, E. M. Logan, G. T. Cook and I. D. Pulford, "A Historical Record of Atmospheric Depositional Fluxes of Contaminants in West-Central Scotland Derived from an Ombrotrophic Peat Core," The Science of the Total Environment, Vol. 222, No. 3, 1998, pp. 157-166. doi:10.1016/S0048-9697(98)00301-5

[7] A. Martinez-Cortizas, X. Pontevedra-Pombal, J. C. Novoa-Munoz and E. Garsia-Rodeja, "Four Thousand Years of Atmospheric $\mathrm{Pb}, \mathrm{Cd}$ and $\mathrm{Zn}$ Deposition Recorded by the Ombrotrophic Peat Bog of Penido Vello (Northwersten Spain)," Water, Air, and Soil Pollution, Vol. 100, No. 3-4, 1997, pp. 387-403. doi:10.1023/A:1018312223189

[8] W. Shotyk, "Natural and Anthropogenic Enrichments of $\mathrm{As}, \mathrm{Cu}, \mathrm{Pb}, \mathrm{Sb}$, and $\mathrm{Zn}$ in Ombrotrophic versus Minerotrophic Peat Bog Profiles, Jura Mountains, Switzerland," Water, Air, and Soil Pollution, Vol. 90, No. 3-4, 1996, pp. 375-405. doi:10.1007/BF00282657

[9] D. Weiss, W. Shotyk, J. D. Kramers and M. Gloor, "Sphagnum Mosses as Archives of Recent and Past At- 
mospheric Lead Deposition in Switzerland," Atmospheric Environment, Vol. 33, No. 23, 1999, pp. 3751-3763. doi:10.1016/S1352-2310(99)00093-X

[10] D. Weiss, W. Shotyk and O. Kempf, "Archives of Atmospheric Lead," Naturwissenschaften, Vol. 86, No. 6, 1999, pp. 262-275. doi:10.1007/s001140050612

[11] D. Weiss, W. Shotyk, E. A. Boyle, J. D. Kramers, P. G. Appleby and A. K. Cheburkin, "Comparative Study of the Temporal Evolution of Atmospheric Lead Deposition in Scotland and Eastern Canada Using Blanket Peat Bogs," The Science of the Total Environment, Vol. 292, No. 1, 2002, pp. 7-18. doi:10.1016/S0048-9697(02)00025-6

[12] D. Weiss, W. Shotyk, J. Rieley, S. Page, M. Gloor, S. Reese and A. Martinez-Cortizas, "The Geochemistry of Major and trace Elements in a Forested Peat Bog, Kalimantan, SE Asia, and Its Implications for Past Atmospheric Dust Deposition," Geochimica et Cosmochimica Acta, Vol. 66, No. 13, 2002, pp. 2307-2323. doi:10.1016/S0016-7037(02)00834-7

[13] S. West, D. J. Charman, J. P. Grattan and A. K. Cheburkin, "Heavy Metals in Holocene Peats from South West England: Detecting Mining Impacts and Atmospheric Pollution," Water, Air and Soil Pollution, Vol. 100, No. 3, 1997, pp. 343-353. doi:10.1023/A:1018393013619

[14] L. Ukonmaanaho, T. Nieminen, N. Rausch and W. Shotyk, "Concentrations of $\mathrm{Cu}, \mathrm{Ni}$ and $\mathrm{Pb}$ at Ombrotrophic Peat Bogs at a Rural Site, Near a Cu-Ni Smelter and Near a Mine," The Science of the Total Environment, Vol. 292, No. 1-2, 2002, pp. 81-89.

[15] L. P. Rikhvanov, E. G. Yazikov, N. V. Baranovskaya, A. M. Belyaeva, L. V. Zhornyak, F. V. Talovskaya, O. A. Denisova and Yu. I. Sukhih, "The State of the Environment Components Tomsk Region According to the Data of ecological-Geochemical Monitoring and the Health of the Population," in Russian, Safety of Live Activity, Vol. 1, 2008, pp. 29-37.

[16] V. M. Gavshin, F. V. Sukhorukov, V. V. Budashkina, M. S. Melgunov and V. A. Bobrov, "Evidence of the Fractionation of Chemical Elements in the Atmosphere of West Siberia According to the Data of the Investigation of a Raised Bog," in Russian, Geochemistry, Vol. 12, 2003, pp. 1337-1344

[17] V. A. Bobrov, V. V. Budashkina, Yu. I. Preis and V. M. Gavshin, "Estimation of the Fluxes of Mineral Matter on the Basis of Trace Element Composition of the Peat of Bakcharskoe Deposit (Tomsk Region)," in Russian, 4th International Scientific-Practical Conference Heavy Metals and Radionuclides in the Environment, Vol. 1, Semipalatinsk, 2006, pp. 141-148.

[18] E. D. Lapshina and E. Ya. Muldiyarov, "The Main Stages of the Development of the Great Vasyugan Bog," In: M. V. Kabanov, Ed., Great Vasyugan Bog. Current Status and Evolution Process, in Russian, Publishing House of the Institute of Atmospheric Optics SB RAS, Tomsk, 2002, pp. 36-44.

[19] D. W. Sheibley, "Trace Elements by Instrumental Neutron Activation Analysis for Pollution Monitoring," In: Advances in Chemistry Series 141 Trace Elements in Fuel, ACS Publications, Washington, DC, 1975, pp. 98117. doi:10.1021/ba-1975-0141.ch009

[20] F. Gauthier-Lafaye, L. Pourcelot, J. Eikenberg, H. Beer, G. Le Roux, L. P. Rikhvanov, P. Stille, Ph. Renaud and A. Mezhibor, "Radioisotope Contaminations from Releases of the Tomsk-Seversk Nuclear Facility (Siberia, Russia)," Journal of Environmental Radioactivity, Vol. 99, No. 4, 2008, pp. 680-693.

[21] L. Ya. Kizil'shtein, "Heavy-Metal Geochemistry of Coal: An Ecological Aspect," Geochemistry International, Vol. 36, No. 8, 1997, pp. 757-761.

[22] V. N. Bashkin, "Environmental chemistry: Asian lessons," Kluwer Academic Publishers, Dordrecht, 2003.

[23] S. I. Arbuzov, V. V. Ershov, A. A. Potseluev and L. P. Rikhvanov, "Rare Elements in Coals of Kuznetsk Basin," Kemerovo, Russia, 2000.

[24] A. M. Adam, Ed., "Ecology of the Northern Industrial Centre: Problems and Solutions," in Russian, Publisher House of Tomsk State University, Tomsk, 1994.

[25] L. P. Rikhvanov, "Radioactive Elements in Environment and Problems of Radioecology," in Russian, STT, Tomsk, 2009. 